\title{
Execution of BLDC Motor using Fuzzy Logic Controller on Propulsion Application for Hybrid Vehicle System
}

\author{
KVNS Pavan Kumar, S.Prakash
}

\begin{abstract}
This research Paper proposes the Brushless DC motors control $(B L D C)$ could accomplish higher execution looking into effectiveness in examination for old brushed DC motor controlling which is difficult to control because it requires a phase for switching circuit. This work proposes a fuzzy logic control for brushless DC motor for axis based on Hall Effect by applying sensor control system and also it produces brushless motor for rearranging the three phase conduction mode model. At long last this paper may be with create efficient control methodologies on enhance driving dynamics on the mechanical dynamic consider of propulsion method. The recommended control method stabilizes those controls services (speeds) done by controller of brushless DC motor drive $(B L D C)$. On behalf of settling 2 wheels also physical favorable circumstances of BLDC motors are associated straight forwardly of the tires by improving the rotor speed. The parameters such as power factor, rotor speed, torque ripple, EMF is compensated \& simulation results are tabulated.

Keywords: BLDC Motor, MATLAB
\end{abstract}

\section{INTRODUCTION}

BLDC motor also called permanent magnet DC synchronous motor has an arrangement depending on points of interest for basic structure, speed torque, high effective response, high life. Jointly every last bit these reductions makes BLDC motors a chance to be additional suitableness alternative for industry for example, such that electric vehicle based propulsion systems, robotics and home appliances [1] [2]. The brushless motor needs an electrical circuit and also operating standards which is compatible to permanent magnet DC machine but this BLDCM requires an electronic control circuit that replaces the collector system in MCC for the entry current which is important phase to process the motor torque that rotates the rotor. Those everlasting magnets of the Brushless motor develops an approach Similarly that prepares a magnetic flux that makes purported nether EMF voltages present in static coils for a trapezoidal shape that controls from that sort of motor relies basically by the voltages brought by the situation of the rotor. To guarantee handy presentation, majority of the data on the situation of the rotor is that main influence but the location data is perfect, superior to those flows toward the near the torque will be reduced, and that ripples need aid those main drawbacks that sort of motors.

Those purpose of the rotor place is completed in dual ways: Initially system may be the sensor low control seemed in 1975 [3], this kind is often dependent upon the identification of the

Revised Version Manuscript Received on 16 September, 2019.

KVNS Pavan kumar, Research scholar, Department of EEE at Bharath Institute of Higher Education and Research, Chennai.

Dr.S.Prakash, Professor, Department of EEE at Bharath Institute of Higher Education and Research, Chennai, India speed range, noise less procedure and more existence the long

back-EMF, those the majority mainstream would those zero crossing [4], the third harmonic detection [5] and the spectators [6], the issue for this kind for command will be that the voltages prompted would low toward low speed and even zero during rest, which strengths the utilization of the assistant start circuit [7] also filter circuits also heavy compensation algorithms [8]

The second control technique will be known as sensored; it utilization location sensors for example, such that encoders or regularly hall Effect sensors put in the stator should figure out those position of the rotor [9]. In the literature, Different control laws have been used, the PID command [9], sliding mode [10], DTC [11]. In this worth of effort also will succeed the parameters of the motor around which those by pulsating torques or whatever available sources of trouble which influences motor desire speed, a closed loop speed control may be actualized utilizing an fuzzy logic controller on focus straightforwardly those duty cycle of the pulse width modulator (PWM) of the DC-DC convertor. This paper available a speed control of a 3-phases BLDC motor, with Hall sensors introduced in the stator. A brushless DC motor drive may be regulated utilizing power electronics converter with give those required control movement of the wheels. The suspension control frameworks created today necessities exact mechanical demonstrating. These mechanical parameters are compelling reason to a chance to have coordinated of the discrete subsystems/workings so as should give vehicle steadiness and controlling [4]. Though, those optimal driving dynamics dismiss just that attain at the tire drives once constantly on wheels besides on the whole 3 guidelines could be impacted and measured unequivocally $[5]$.

\section{BLDC MOTOR}

The measured brushless DC engine comprises of a three phase winding stator likewise a lasting order rotor fig. 1 and its windings compelling reason help star joined. The engine might be functioned to two periods conduction mode to which each period voltage will make energized with a between time starting with interim about $120^{\circ}$ electrical Similarly as expressed Eventually Tom's perusing the rotor electrical position, in a far-reaching way there need aid six separate sectors, it need on furnish two stages are powered, person is connected with those sure terminal of the dc transport +VDC and the separate will -VDC, fig. 2. That rise to model of the BLDCM drive system by the suspicion about three-phase symmetric stator windings will be indicated in fig. 1 . 


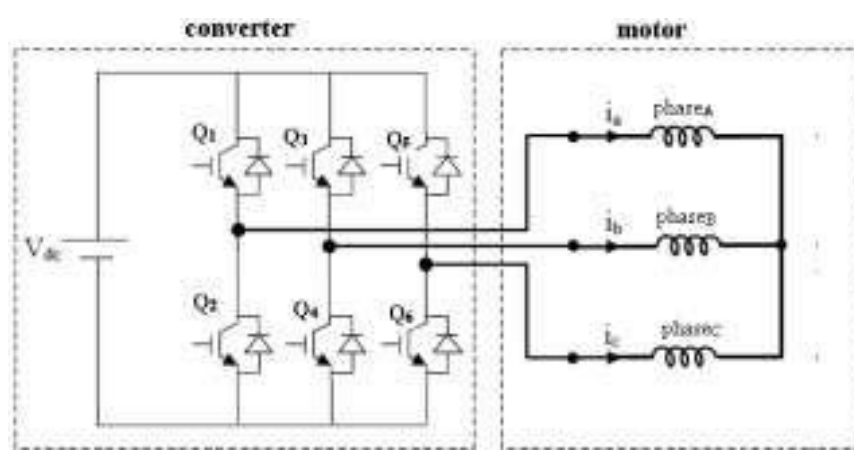

Figure.1. BLDC motor for full bridge driving circuit

The below equation have been derived the terminal voltage of three phase stator winding is stated as

$$
\left\{\begin{array}{l}
\mathrm{V}_{\mathrm{a}}=\mathrm{Ri}_{\mathrm{a}}+\mathrm{L} \frac{\mathrm{di}_{\mathrm{a}}}{\mathrm{dt}}+\mathrm{e}_{\mathrm{a}} \\
\mathrm{V}_{\mathrm{b}}=\mathrm{Ri}_{\mathrm{b}}+\mathrm{L} \frac{\mathrm{di}_{\mathrm{b}}}{\mathrm{dt}}+\mathrm{e}_{\mathrm{b}} \\
\mathrm{V}_{\mathrm{c}}=\mathrm{Ri}_{\mathrm{c}}+\mathrm{L} \frac{\mathrm{di} \mathrm{i}_{\mathrm{c}}}{\mathrm{dt}}+\mathrm{e}_{\mathrm{c}} \\
\mathrm{T}_{\mathrm{em}}=\frac{\mathrm{e}_{\mathrm{a}} \mathrm{i}_{\mathrm{a}}+\mathrm{e}_{\mathrm{b}} \mathrm{i}_{\mathrm{b}}+\mathrm{e}_{\mathrm{c}} \mathrm{i}_{\mathrm{c}}}{\Omega}
\end{array}\right.
$$

Here $\mathrm{Va}, \mathrm{Vb}, \mathrm{Vc}$ are voltages, Ia, Ib, Ic are currents and ea, $\mathrm{eb}$, ec are the phase EMF of the terminal for 3 phase stator

\begin{tabular}{|c|c|c|c|c|c|c|c|}
\hline Seq & \multicolumn{3}{|c|}{ Hall Sensors } & $\begin{array}{l}\text { Active } \\
\text { switches }\end{array}$ & \multicolumn{3}{|c|}{ Phases currents } \\
\hline & $\mathrm{C}$ & B & A & & $\mathrm{C}$ & B & A \\
\hline 1 & 1 & 0 & 1 & Q1-Q4 & OFF & DC- & $\mathrm{DC}+$ \\
\hline 2 & 1 & 0 & 0 & Q5-Q4 & $\mathrm{DC}+$ & DC- & OFF \\
\hline 3 & 1 & 1 & 0 & Q5-Q2 & DC+ & OFF & DC- \\
\hline 4 & 0 & 1 & 0 & Q3-Q2 & OFF & $\overline{\mathrm{DC}+}$ & DC- \\
\hline 5 & 0 & 1 & 1 & Q3-Q6 & DC- & $\mathrm{DC}+$ & OFF \\
\hline 6 & 0 & 0 & 1 & Q1-Q6 & DC- & OFF & $\mathrm{DC}+$ \\
\hline
\end{tabular}
winding, $\mathrm{R}$ is the resistance and $\mathrm{L}$ is the inductance of stator where $\Omega$ stands for rotor angular velocity of electromagnetic torque.

Table.1. Truth table for Hall effect sensors and gate states

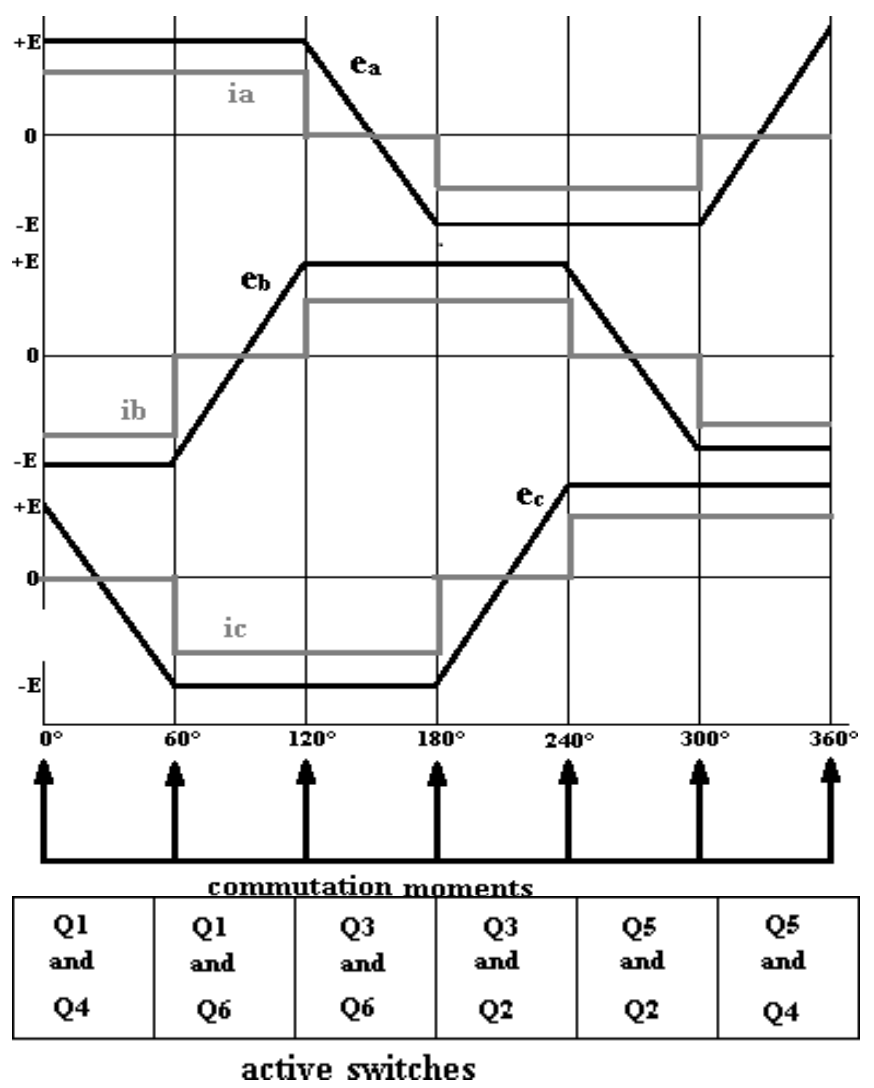

Fig.2. Six steps switching sequence

\section{BLDC MOTOR CONTROL SCHEME}

\subsection{Simplification model}

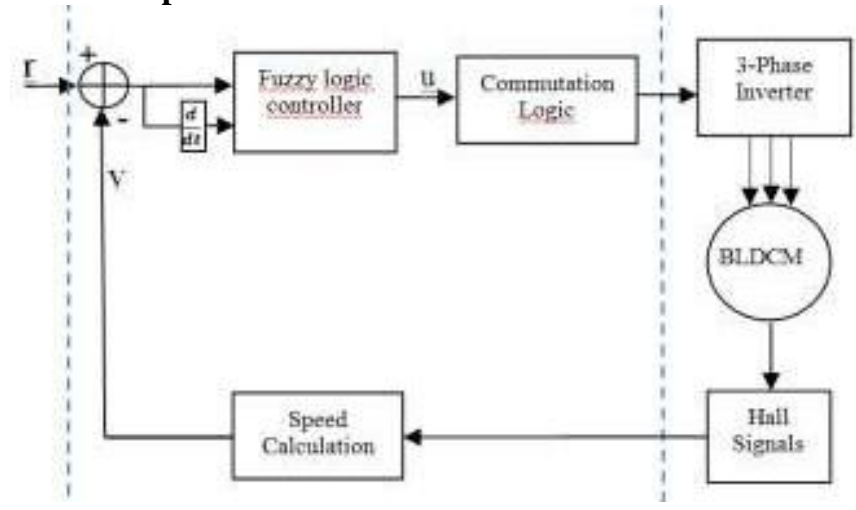

Figure.3. BLDC motor Circuit

Initial sequence characterized by $I_{a}=1, I_{b}=1, I_{c}=0$ where $U_{a b}$ is greater than 0

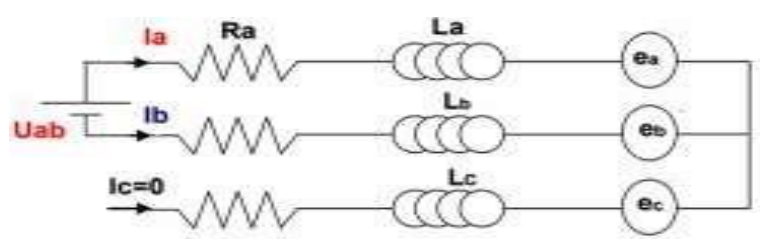

Figure.4. BLDC motor circuit for the sequence 1 Consider $\mathrm{Ra}=\mathrm{Rb}$ and $\mathrm{Ra}=\mathrm{Rb}$. we have: 


$$
\begin{aligned}
& \mathrm{V}_{\mathrm{a}}=\mathrm{RI}+\left(\mathrm{L}_{\mathrm{a}}-\mathrm{M}\right) \frac{\mathrm{dI}}{\mathrm{dt}}+\mathrm{E}_{\mathrm{a}} \\
& \mathrm{V}_{\mathrm{b}}=\mathrm{RI}+\left(\mathrm{L}_{\mathrm{b}}-\mathrm{M}\right) \frac{\mathrm{dI}}{\mathrm{dt}}+\mathrm{E}_{\mathrm{b}}
\end{aligned}
$$

Where: $\mathrm{L}=(\mathrm{La}-\mathrm{M})$ and $\mathrm{M}$ is the mutual stator inductance. We have:

$$
\mathrm{E}_{\mathrm{a}}=-\mathrm{E}_{\mathrm{a}}=\mathrm{K} \Omega=\mathrm{E}_{\mathrm{m}}
$$

Thus the expression of Uab is:

$$
\mathrm{U}_{\mathrm{ab}}=\mathrm{V}_{\mathrm{a}}-\mathrm{V}_{\mathrm{b}}=2 \mathrm{R}_{\mathrm{a}} \mathrm{I}+2\left(\mathrm{~L}_{\mathrm{a}}-\mathrm{M}\right) \frac{\mathrm{dI}}{\mathrm{dt}}+2 \mathrm{E}_{\mathrm{m}}
$$

By posing

$$
\mathrm{R}=2 \mathrm{R}_{\mathrm{a}}, \mathrm{L}=2\left(\mathrm{~L}_{\mathrm{a}}-\mathrm{M}\right) \text { and } \mathrm{E}=2 \mathrm{E}_{\mathrm{m}}
$$

We obtain an expression which is the same as the electrical equation of the DC machine:

$$
\mathrm{U}_{\mathrm{ab}}=\mathrm{RI}+\mathrm{L} \frac{\mathrm{dI}}{\mathrm{dt}}+\mathrm{E}
$$

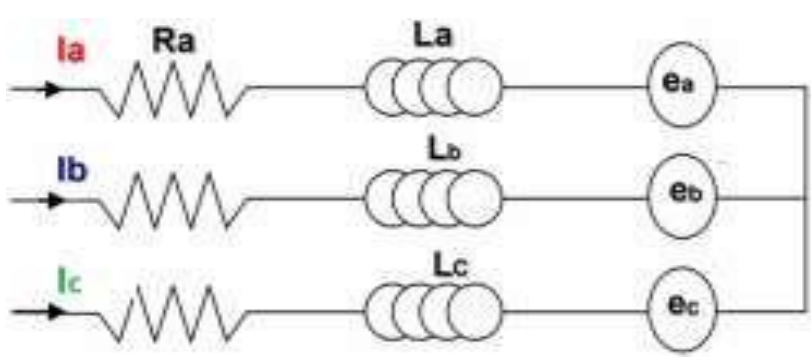

In the same way, study the additional zone; lead us of the electrical comparison of a DC motor over. The control of the self driven BLDC motor may be accordingly comparable on independently energized DC motor the place the speed will be directly proportional to the voltage connected of the motor terminals.

$$
\Omega=\mathrm{K} * \mathrm{~V} \text { and } \mathrm{V}=\left(\frac{\mathrm{DT}}{\mathrm{T}} / \mathrm{T}\right) * \mathrm{~V}_{\text {bus }}
$$

Here $\mathrm{T}$ is said to be the switch cycle and $\mathrm{d}$ is the duty cycle shown in fig $5 . \Omega$ is said to be rotor speed and $V_{\text {bus }}$ is the DC input voltage of inverter and $\mathrm{K}$ is the speed ratio of the motor.

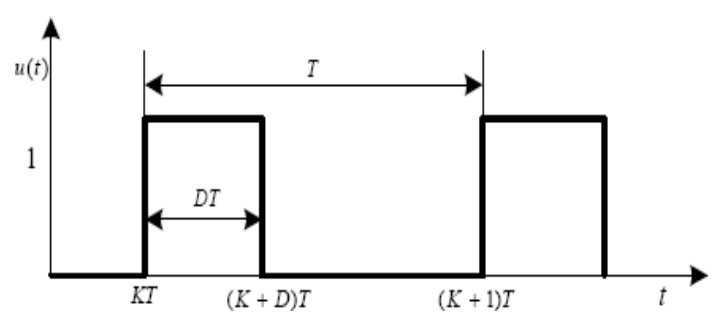

Figure.5. PWM switching inverter in impulse mode

\section{FUZZY LOGIC CONTROLLER}

Today, fuzzy regulation may be an main branch about regulation innovation. The fuzzy controller need attained those best achievement over industrial furthermore business applications for fuzzy techniques. Fuzzy controller would nonlinear controllers. Three phases about treatment occur for an fuzzy controller figure.6. fuzzification and defuzzification [10].

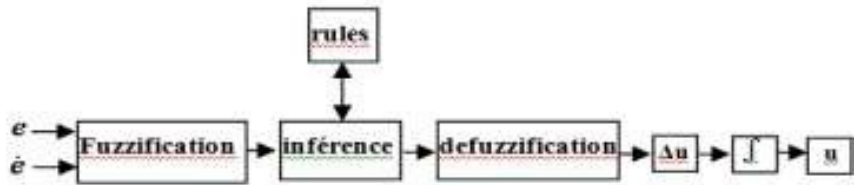

Figure.6. Fuzzy logic controller

Fuzzification : here this step transforms and measures the method under fuzzy situation by the ability to take the necessary number of characterization and allocation of fuzzy sets shown in fig 7 .

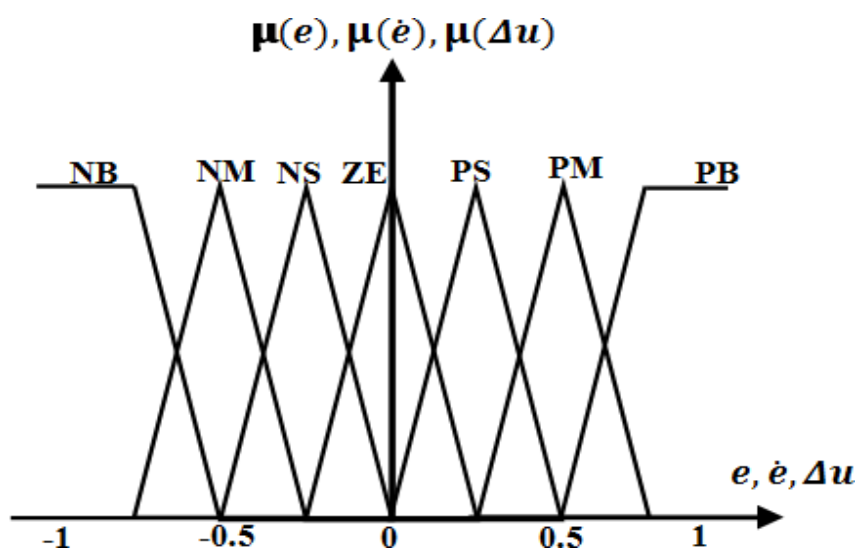

Fig. 7. Membership plot for input and output Inference: It comprises and connects the input variables of regulator by output variables of linguistic mental rules recognized by human capability shown in table 2.It interprets the movement or semantic choices for supervising the retreat controller from front side in any circumstance that shows the entrance of the controller. Every rule is made up of the state depending on symbol 'IF' for beginning and symbol 'THEN' for the conclusion.

Defuzzification: In order to have the concern on the membership functionality and establishing the rules of the activity we introduce the defuzzification state that transforms the control value to fuzzy domain and then to signal domain.

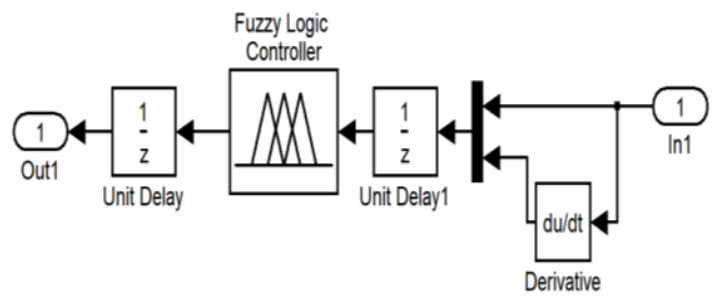

Fig. 8. System structure of fuzzy logic control. 


\begin{tabular}{|c|c|c|c|c|c|c|c|c|}
\hline \multirow{2}{*}{\multicolumn{2}{|c|}{$\Delta \mathbf{u}$}} & \multicolumn{7}{|c|}{$\dot{\boldsymbol{e}}$} \\
\hline & & \multirow{2}{*}{$\frac{\text { NB }}{Z}$} & \multirow{2}{*}{$\begin{array}{l}\text { NM } \\
\text { NS }\end{array}$} & \multirow{2}{*}{$\frac{\mathrm{NS}}{\mathrm{NM}}$} & \multirow{2}{*}{$\begin{array}{l}\text { ZE } \\
\text { NB }\end{array}$} & \multirow{2}{*}{$\begin{array}{l}\text { PS } \\
\text { NB }\end{array}$} & \multirow{2}{*}{$\begin{array}{l}\text { PM } \\
\text { NB }\end{array}$} & \multirow{2}{*}{$\begin{array}{l}\text { PB } \\
\text { NB }\end{array}$} \\
\hline \multirow{7}{*}{$e$} & NB & & & & & & & \\
\hline & NM & PS & $\mathbf{Z E}$ & NS & NM & NB & NB & NB \\
\hline & NS & $\overline{\mathbf{P M}}$ & PS & $\mathbf{Z E}$ & NS & NM & NB & NB \\
\hline & ZE & PB & PM & PS & $\mathbf{Z E}$ & NS & NM & NB \\
\hline & PS & PB & PB & PM & PS & $\mathbf{Z E}$ & NS & NM \\
\hline & PM & PB & PB & PB & PM & PS & $\mathbf{Z E}$ & NS \\
\hline & PB & PB & PB & PB & PB & PM & PS & $\mathbf{Z E}$ \\
\hline
\end{tabular}

Table.1. Rule based Fuzzy

\section{CONTROLLER IMPLEMENTATION}

In those start we continued to the standardization of input and output yield to controller would the sum converted should a quality the middle of -1 and 1 so we divide and derivate the errors depending on highest values. Integrated circuit provides the worth of the duty cycle for attacking the motor by taking the output values among -1 to 1 and multiplies them by front values.

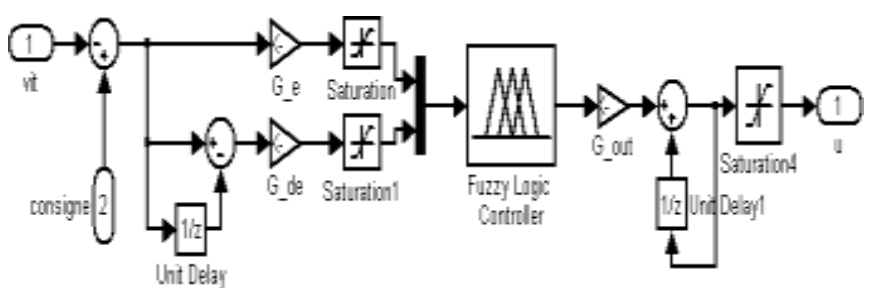

Figure.9. Fuzzy logic controller in simlink scheme

$\mathrm{Ge}=1 / 3000$ input error gain i.e created among -1 and 1 which is divideddepending on the highest speed value, Gde $=1 / 33$ error derivative gain used for the difference for high value varied from open loop test. e(k)-e(k-1),33 is the high value and Gout $=0.03$ is a calculation step for $0.1 \mathrm{~ms}$.

\section{Electric Vehicle based Propulsion System}

Fig.10.General electric vehicle based propulsion system configuration

\section{SIMULATION RESULT \& ANALYSIS}

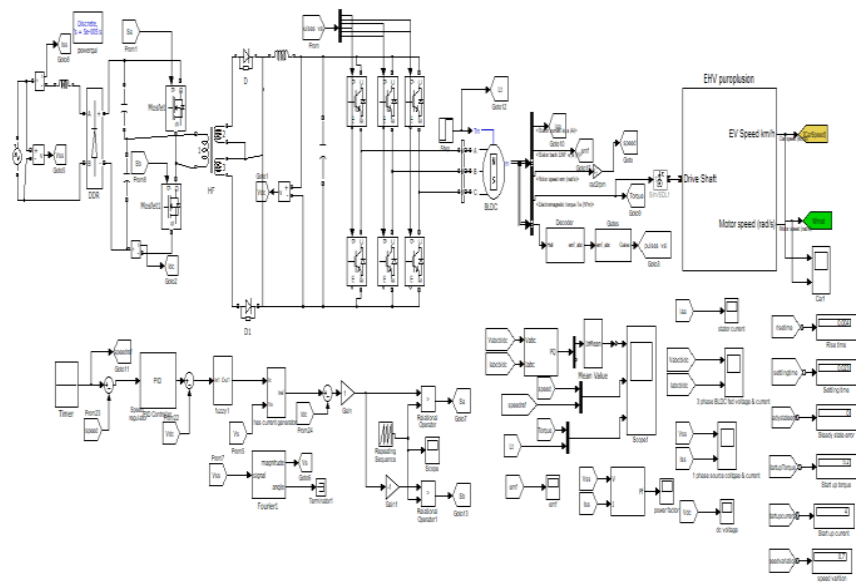

Fig.11 simulation design of fuzzy based BLDC propulsion system

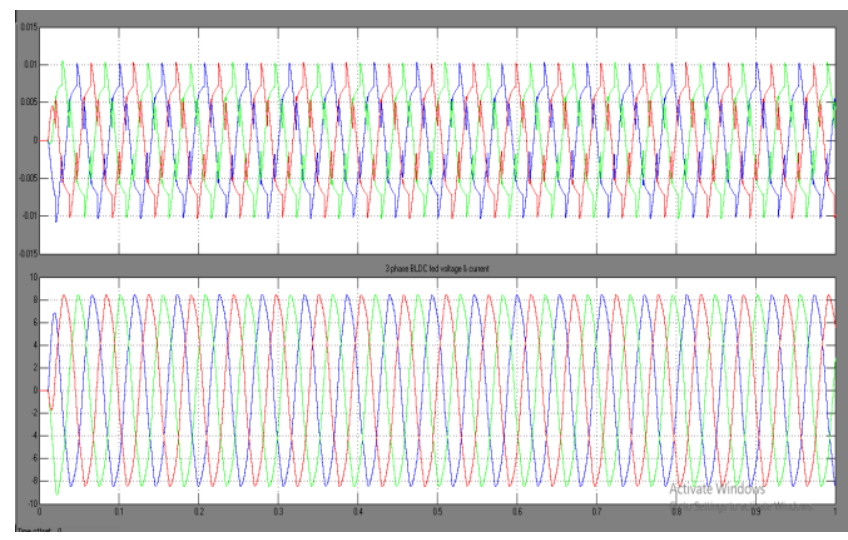

Fig. 12: 3 phase BLDC fed voltage \& current

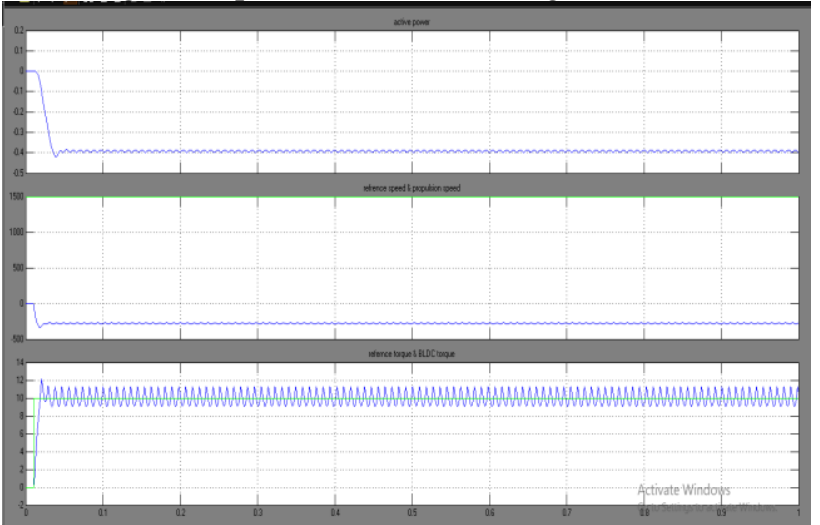

Fig 13: (a) active power (b) reference speed \& propulsion speed (c) reference torque \& BLDC torque
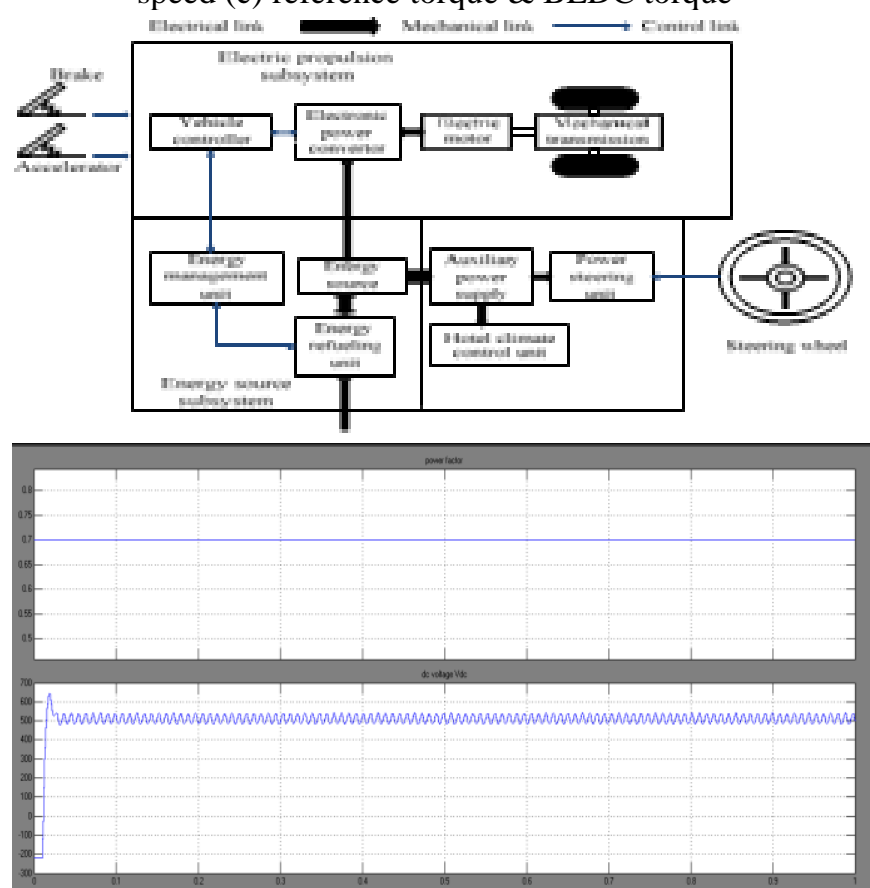

Fig 13: power factor (PF 0.7) \& dc voltage (Vdc 500) 


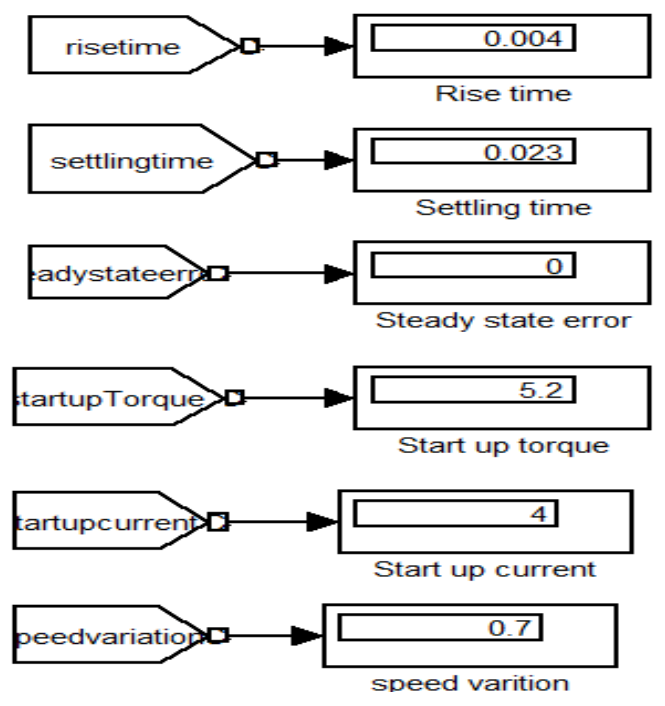

\begin{tabular}{|c|c|c|c|}
\hline \multicolumn{2}{|l|}{ Parameters } & PI \& PID & FUZZY \\
\hline \multirow[b]{2}{*}{ Rise time } & 0-700 RPM & 0.005 & 0.004 \\
\hline & 700-900RPM & 0.005 & 0.003 \\
\hline \multirow[b]{2}{*}{$\begin{array}{l}\text { Settling } \\
\text { time }\end{array}$} & 0-700 RPM & 0.025 & 0.023 \\
\hline & 700-900RPM & 0.0075 & 0.005 \\
\hline \multirow[b]{2}{*}{$\begin{array}{l}\text { Steady state } \\
\text { error }\end{array}$} & 0-700 RPM & $0 \%$ & $0.7 \%$ \\
\hline & 700-900RPM & $0 \%$ & $0.7 \%$ \\
\hline \multirow[b]{2}{*}{$\begin{array}{l}\text { Start up } \\
\text { torque }\end{array}$} & 0-700 RPM & 7.9M.M & 5.2 N.N \\
\hline & 700-900RPM & 2.2N.M & 2.3 N.M \\
\hline \multirow[b]{2}{*}{$\begin{array}{l}\text { Start up } \\
\text { current }\end{array}$} & 0-700 RPM & $6 \mathrm{~A}$ & $4 \mathrm{~A}$ \\
\hline & 700-900RPM & $2 \mathrm{~A}$ & $2 \mathrm{~A}$ \\
\hline $\begin{array}{l}\text { Rapidity } \\
\text { variation }\end{array}$ & \multicolumn{2}{|l|}{$0.8 \%$} & $0.7 \%$ \\
\hline $\begin{array}{l}\text { Power } \\
\text { factor }\end{array}$ & \multicolumn{2}{|l|}{0.2} & 0.7 \\
\hline DC voltage & \multicolumn{2}{|l|}{-300} & $500 \mathrm{Vdc}$ \\
\hline
\end{tabular}

Table.2. Comparison between Pi and PID vs Fuzzy controller

\section{CONCLUSION}

This research work presented a speed control and torque ripple decrees of the BLDC motor utilizing an advance fuzzy and Hall Effect sensors. A fuzzy logic controller is actualized should control those motor speed. This work developed a single model of mechanical dynamics of a 2- wheel. In this paper we can find that power factors is $0.7 \mathrm{dc}$ injected voltage is about $500 \mathrm{~V}$ dc for analyzing and simulating results. In order to test the controller performance of BLDC drive a simulation must be created. The torque balances the EV for stabilization of the vehicle during emergency and standard driving for drivers. Diverse determination cycles are mimicked also exhibited. In any case we haven't investigated that framework in distinctive state. Next critical examination of the framework in distinctive state will make the future more attractive.

\section{REFERENCES}

1. W. Wang, B. Fahimi, Comparative Study of Electric Drives for EV/HEV propulsion systems, IEEE Transportation Electrification Conference and Expo (ITEC), 2012.

2. J. Kammermann, I. Bolvashenkov, H.-G. Herzog, Approach for Comparative Analysis of Electric Traction Machines, 3rd International Conference on Electrical Systems for Aircraft, Railway, Ship Propulsion, and Road Vehicles (ESARS) Aachen, Germany, March 2015, pp.1-5.

3. M. Zeraoulia, M. E. H. Benbouzid, D. Diallo, Electric Motor Drive Selection Issues for HEV Propulsion Systems: A Comparative Study, IEEE Transactions on Vehicular Technology, Vol. 55, No. 6, November 2006.

4. J. C. Dixon, "Tires, Suspension, and Handling, Society of Automotive Engineers, 2nd edition, 1996.

5. E. Donges, "Supporting drivers by chassis control systems", in Smart Vehicles, J.P. Pauwelussen, H.B. Pacejka (eds.), pp. 276-296, Delft, 1995.

6. B. Brandt, 'Build Your Own Electric Car, TAB Books, 1994.

7. Ching-Tsai Pan and Ting-Yu Chang, "An improved hysteresis current controller for reducing switching frequency," in IEEE Transactions on Power Electronics, vol. 9, no. 1, pp. 97-104, Jan 1994.

8. M. F. Rahman, K. S. Low and K. W. Lim, "Approaches to the control of torque and current in a brushless DC drive," 1993 Sixth International Conference on Electrical Machines and Drives (Conf. Publ. No. 376), Oxford, 1993, pp. 594-599

9. Shi, Y. Guo, P. Song, and C. Xia, "A new approach of minimizing commutation torque ripple for blushless dc motor based on $\mathrm{dc}-\mathrm{dc}$ converter,” IEEE Trans. Ind. Electron., vol. 57, no. 10, pp. 3483-3490, Oct. 2010

10. Z. Q. Zhu and D. Howe, "Electrical machines and drives for electric, hybrid, and fuel cell vehicles," Proc. IEEE, vol. 95, no. 4, pp. 746 765, Apr. 2007.

11. J.R. Frus and B. C. Kuo, ,„,Closed-loop control of step motors using waveform detectio,in Proc. Int. Conf. Stepping Motors and Systems, Leeds, U.K., 1976, pp. 77_84.

12. X. Zhou, X. Chen, M. Lu, et al., "Rapid Self-Compensation Method of Commutation Phase Error for Low Inductance BLDC Motor," IEEE Trans. Ind. Inform., vol. 13, pp.1833-1842, Aug.2017.

13. J. C. Moreira, "Indirect sensing for rotor flux position of permanent magnet AC motors operating over a wide speed range," IEEE Trans.Ind. Appl., vol. 32, no. 6, pp. 1394-1401, Nov./Dec. 1996. 